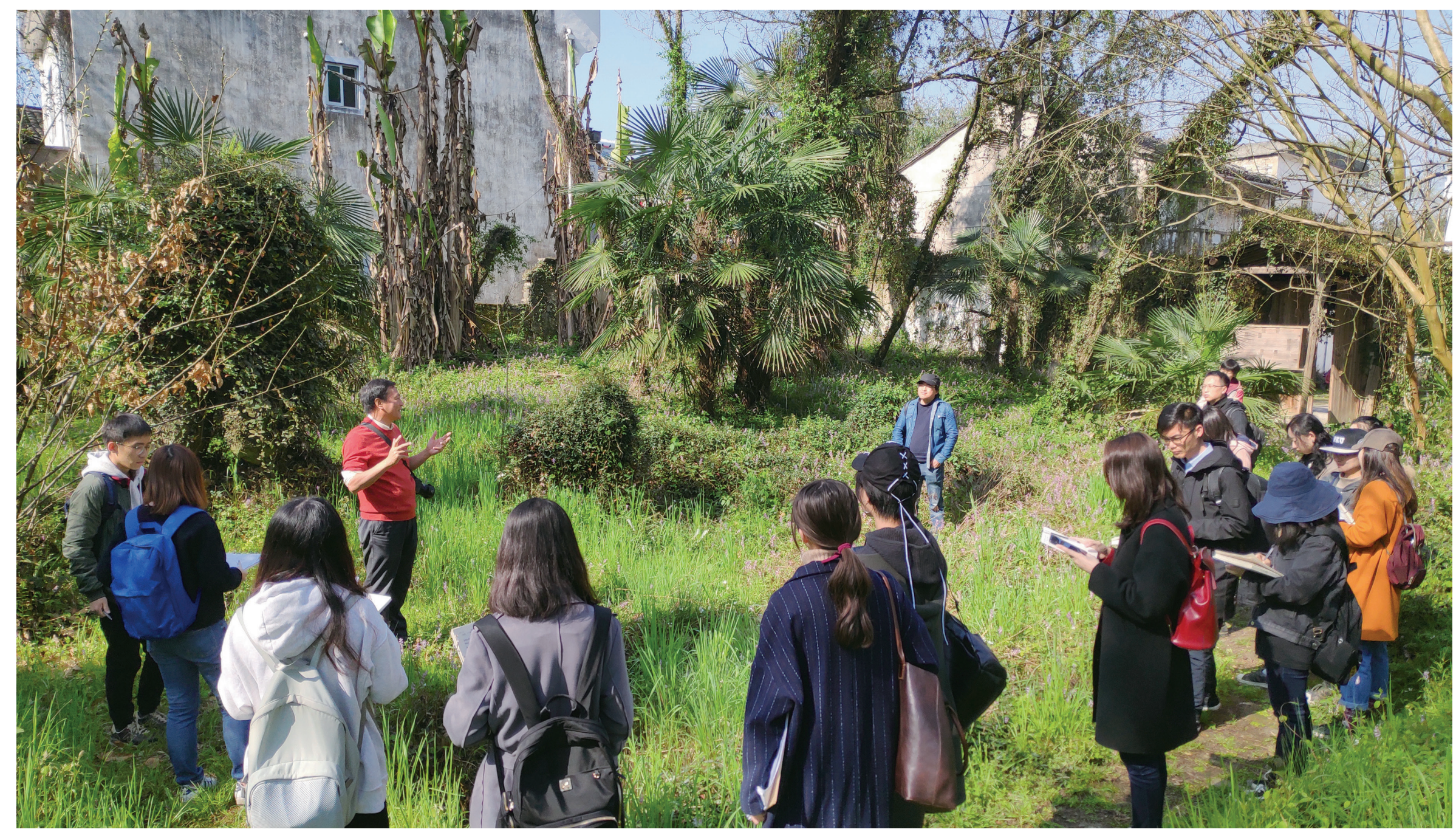


EDITORIAL

主编寄语

中国的乡村振兴是一个需要通过实践研究来探索其实现路径和策略的宏大课题, 涉 及农民的生存与发展、农业效率和农产品品质的提升、宅基地产权登记与管理, 以及生 态和文化遗产保护等多方面的问题, 目前尚无可以推而广之的模式。为此, 北京大学建 筑与景观设计学院团队已连续多年致力于乡村振兴的实践研究, 并在安徽省黄山市徽州 区建立了可以长期观察乡村生活的 “望山生活” 实验基地。图为学院师生在徽州区西溪 南村开展实践研究的场景。

Date April 1, 2019 Location Xixinan Village, Huizhou District, Huangshan City, Anhui Province

Rural revitalization in China is an ambitious agenda which needs efforts of practice research to explore the paths and strategies, ranging from the survival and development of farmers, the enhancement of productivity, the quality improvement of agricultural products, the registration and management on homestead property right to ecological protection and cultural heritage conservation. However, it has not seen any solution that can be applicable to all the regions throughout the country. After years of practice research on rural revitalization, a team from the College of Architecture and Landscape of Peking University has been working on addressing such issues by founding the Wangshan Life Laboratory in Huizhou District of Huangshan City, Anhui Province, which studies rural localities through long-term field observation. In the photo, teachers and students of the college were in a field trip for practice research. 


\section{实践研究: 创新知识和方法的范式}

俞孔坚

哈佛大学设计学博士; 美国艺术与科学院院士; 北京大学建筑与 景观设计学院教授

翻译 田乐 王胤瑜 田晓劼

\section{摘要}

通过回顾 “北大 - 土人” 实践研究的模式以 及遇到的种种挑战, 作者总结了三点思考：1） 实践研究的意义在于在不断的尝试中积累经验, 最终获得有用的知识和解决实际问题的方法；2） 实践研究主体一般为院校教师、科研机构的研究 员、学生, 以及在实践一线的规划设计师, 但国 内现行的学术考核方式过度追求论文引用而非实 践成就, 甚至有着深厚研究传统的规划设计研究 院也鲜有时间精力对实践中的问题进行深入探 讨，以致模式套用成风； 3 ) 规划设计实践的充 分市场化才是实践研究可持续发展的不竭动力。 “原型研究” 作为实践研究的一种, 将有助于不 断拓宽景观设计学科的发展路径, 为设计师及相 关领域的学者提供前瞻性的设计思路和更具韧性 的工作方法, 以适应充满不确定挑战的未来。

\section{关键词}

实践研究；规划设计；知识创新；范式；学科发展
2020年6月9日晚，一场中美国际线上研讨会持续了近两个小时。这是 “实践研究” 系列 讨论的第一场，旨在揭示大学和规划设计机构如何通过研究，就具体实践问题实现理论、方法 和技术创新，并促进相关应用与推广。

本次研讨会由麻省理工学院终身教授、著名景观和生态学者安妮・惠斯顿・斯本发起。 她曾深入研究美国生态规划的开创者伊恩 - L - 麦克哈格在宾夕法尼亚大学和他本人创立的 WMRT事务所进行的实践研究（包括其著名的创新性实践研究成果《设计结合自然》），以 及两个机构间的互动关系。她亦非常好奇中国的相关实践研究如何进行, 并为此于麻省理工学 院设立了专门的研究课题，重点探讨过去20年间北京大学建筑与景观设计学院和土人设计的 实践研究, 以及这两个机构之间如何互动并进行知识创新, 以解决中国城镇化过程中出现的紧 迫问题。受斯本教授的启发，我回顾了“北大-土人” 实践研究的模式以及遇到的种种挑战， 由此总结了三点思考, 与读者分享:

第一, 为什么要做实践研究? 当我们面对全新而陌生的问题，且缺乏成熟的解决方案或技 术支持时，针对性研究便十分必要。例如，由于文化背景、社会制度及地域条件的不同，中国 城镇化进程中出现的一系列城市问题，均难以从其他国家的经验和教训中直接找到可靠的预测 模式和可借鉴的解决方案; 同时，现存的理论方法繁多，但哪种方法更适用于当下中国所面临 的具体问题亦不得而知。在某种意义上, 这便是 “摸着石头过河”一一只有通过实践研究才能 得到真正有用的知识和解决实际问题的方法，在不断的尝试中积累经验，最终解决问题。

第二, 谁来做实践研究? 一般而言, 院校教师、科研机构的研究员、学生, 以及在实践一 线的规划设计师是实践研究的主体。但事实上，国内现行的学术考核方式并不鼓励实践研究， 而是片面追求论文引用, 对实践的理解偏差使得学者更倾向于做学究式的研究, 从故纸堆里去 寻找课题，热衷于申请由政府设立的所谓 “纵向项目”，而较少考虑由企业资助的、用于解决 实际问题的 “横向项目”。在成果评定中，直接与社会实践相结合的研究课题或多或少会受到 忽视。事实上, 在 “以文章论英雄” 的大学里, 从职位招聘开始就已经注定了实践研究的弱势 地位，也奠定了院校的研究氛围：脱离实践的空泛研究不仅于解决当下的实际问题毫无益处， 也使学生们在毕业后无法快速适应社会需求。长此以往, 学科和专业的创新能力和解决问题的 能力便每况愈下，学科也将失去其存在的意义。

在中国的城镇化和市场化的大潮到来之前, 规划设计机构原本有着非常深厚的研究传统, 为解决城乡发展过程中的症结开展了大量名副其实的研究, 因此常被称为 “规划设计研究 院”。后来, 越来越多的研究院所改制为公司, 进入市场; 与此同时, 在巨变的社会经济环境 中, 新问题层出不穷, 对知识创新和模式创新的需求也随之增加。然而, 模式套用之风大行其

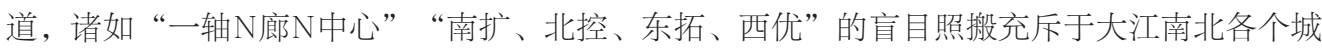
市的规划中, “跨江发展” “向海发展” 成了套路, 滨江大道、滨河大道蔚然成风。建筑与景 观设计行业中千篇一律、自欺欺人的规划设计招投标、恶劣的低价竞标，以及近 20 年不变的 低取费标准，导致规划设计人员鲜少能够投入足够的时间精力对实践中的问题进行深入研究， 由此造成行业内劣币驱逐良币、从业者薪资和企业利润低下的状况，整体上使一个具有研究性 的实践行业退化为 “廉价劳动力” 主导的生产性行业。在自然资源保护与城乡规划系统内, 专 业和行业难以适应国家行政机构的调整和国家需求的重大转变, 亦暴露出过去数十年来实践研 究的严重缺位。 


\section{PRACTICE \\ RESEARCH: \\ A PARADIGM FOR THE INNOVATION OF KNOWLEDGE AND METHODOLOGY}

\author{
YU Kongjian \\ Doctor of Design at Graduate School of Design, Harvard \\ University; Honorary Foreign Fellow of the American \\ Architecture and Landscape, Peking University
}

TRANSLATEd BY Tina TIAN WANG Yinyu TIAN Xiaojie

\section{ABSTRACT}

In this article, the author concluded the patterns and challenges of practice research by Peking University-Turenscape into the answers to three questions: 1) By conducting practice research, people can gain the knowledge and methodologies to address authentic practice issues with constant attempts; 2) College faculties and students, researchers, and planners / designers are the agencies of practice research, but they are in dilemma because of the over pursuit for paper publication and citation in academic performance assessment, and the insufficient time and budget for research leading a fact that generic planning schemes and stereotypes are popularly employed; And 3) the healthy development and long-term promotion of practice research relies on the growth of the market-oriented industry. As one type of the practice research, "prototype study" offers a paradigm for the innovation of knowledge and methodology. Oriented to future challenges and uncertainties, it would help extend the horizon of Landscape Architecture, providing designers and scholars with prospective design insights and flexible working methods.

\section{KEYWORDS}

Practice Research; Planning and Design Knowledge Innovation; Paradigm; Disciplinary Development
In the evening of June 9, 2020, a two-hour online China-US seminar took place as the first session of the Practice Research serial seminars, aiming to explore what planning and design colleges and institutions should do to encourage theoretical, methodological, and technological innovations on practical issues and promote associated applications.

This seminar was initiated by Anne Whiston Spirn, a tenured professor of MIT and a reputed landscape architect and ecologist. She has conducted extensive studies on the practice research carried out by Ian L. McHarg at the University of Pennsylvania and the WMRT Firm led by himself, including one of his most notable achievements of innovative practice research, Design with Nature. Meanwhile, she is curious about the practice research in China, and has started a program at MIT focusing on the work of the College of Architecture and Landscape of Peking University and Turenscape over the past two decades, and how the interaction between research and practice has promoted knowledge innovation to address the pressing issues of the urbanization in China. Inspired by Professor Spirn, my thoughts on the patterns and challenges of practice research by Peking University-Turenscape can be concluded into the answers to three questions:

First, why do we need practice research? Targeted practice research can help improve our understanding to new discourses and generate theoretical guidance or technical roadmaps to new challenges. For instance, issues arising midst the urbanization in China see few references of prediction patterns or solutions from other countries, given the regional differences in cultural contexts, social institution, and geographical conditions. Also, the applicability of the current wide-ranging theories and methods remains unknown to Chinese cases. In some sense, it requires the spirit of "crossing the river by feeling the stones"- Only by conducting practice research can we gain the knowledge and methodologies to address authentic practice issues with constant attempts.

Second, who does practice research? They can be college faculties and students, researchers, and planners / designers. However, the instructional evaluation of faculties of most Chinese design colleges measures the number of published papers and citations, rather than practice research, leading to a pedantic ecology where scholars are keen on studying the subjects commissioned by the government, instead of those sponsored by private enterprises coping with the problems in practice. In addition, the subjects on social topics are usually less studied. This "paper-first" instructional institution also defines the faculty structure of colleges and universities, neglecting practice research in curriculum design and teaching systems. The research that divorces from practice is bound to fail to solve actual problems, and such a college training would not guarantee the graduates to be prepared for real design tasks. This deteriorates the innovation capacity and problem-solving ability of design professionals and hinders the development of design disciplines to respond to contemporary missions

In China, before the aggressive urbanization and market reform, many state-owned planning and design institutes had a good tradition of "practice as research" with authentic cases of urban-rural development; Afterwards, with the rapid changes of China's socio-economic environment, these institutes have finished their transformation into capital-driven firms, which have faced new challenges in knowledge and technical innovation and working-mode reform so as to fulfill the profession's contemporary tasks. However, generic planning schemes are popularly employed, and stereotypes like "axes-corridorscenters," "cross-river development," or "coastal growth" are prevailing across China. Worse, the fraudulent or vicious bidding and the low payment standard never raised for almost 20 years have hindered the industry's inputs in practice research. As a result, planning and design professionals have seen a degradation in research capacity and innovative intelligence, who now become nothing but "cheap labor force" for repetitive works, failing to respond to the new requirements of the state's institutional reforms in natural resource conservation and urban-rural planning. 
第三, 面对当前的不利状况, 如何推动实践研究和知识创新? 首先, 我们希望高校及研究 机构能够认识到实践研究的价值, 并由此改变各种有损于实践研究积极性的 “指挥棒” ——事 实上, 此次新冠肺炎疫情已经以生命为代价, 无情地揭示了中国实践研究的窘境, 也迫使有关 部门名义上取消了唯论文和引用率为导向的评价体系 ${ }^{[1]}$; 其次, 少数有情怀的学者对社会问题 异常敏感, 且富有研究热情, 他们利用自身影响力引领后辈积极开展实践研究, 这些努力和尝 试应该被鼓励; 再次, 随着市场机制逐步发挥作用, 实践研究将使研究性规划设计机构具备持 续的竞争优势, 使他们可以有更高的取费用于长期创新和研发, 用更高的薪酬吸引优秀人才, 以形成市场选择下优胜劣汰的良性循环。正如恩格斯百余年前所言：社会一旦有技术上的需 要, 则这种需要就会比十所大学更能把科学推向前进 ${ }^{[2]}$ 。因此, 规划设计实践的充分市场化是 实践研究最终获得重视和可持续发展的真正动力。

苟日新, 日日新, 又日新 ${ }^{[3]}$ 。实践研究是面对动态的社会和自然挑战, 不断创新思想、理 论、方法和技术的必由途径, 对于景观设计和城乡规划设计学科而言尤其如此。说到底, 规划 设计实践本身就是针对某一个或一组问题, 寻求最优解的研究过程。而本期所探讨的 “原型研 究” 作为一种创新知识和方法的范式, 即为实践研究的一种。面向未来挑战的原型研究成果将 不断拓宽景观设计学科的发展路径, 为设计师及相关领域的学者提供更具前瞻性的设计思路和 更有弹性的工作方法, 以促使我们更好地适应充满不确定性挑战的未来。 
Third, how to promote practice research and knowledge innovation? First of all, colleges and research institutes should re-emphasize the importance of practice research for design disciplines, and then abolish the mechanisms impeding research enthusiasm - Alarmed by the cost of lives during COVID-19 pandemic and the problems exposed in this period, the "paper-first" evaluation system of college faculties has been called off by related departments ${ }^{[1]}$. Moreover, researchers who are enthusiastic for addressing social issues through design interventions and influencing younger scholars to put more efforts in practice research should be more rewarded. Also, the increasingly market-oriented industry is reshaping the climate in the fields of planning and design, where the institutes good at practice research would be more competitive in business and talent recruitment. As stated by Friedrich Engels over a century ago, one market demand works better than ten universities to stimulate technical progress ${ }^{[2]}$. Therefore, the healthy development and long-term promotion of practice research relies on the growth of the market-oriented industry.

As an ancient Chinese adage advises, if one can make things better for one day, he should make them better every day ${ }^{[3]}$. In face of the ever-changing social and natural challenges, practice research paves the path for innovations in theory, methodology, and technology. This is particularly true for Landscape Architecture and Urban and Rural Planning, because planning and design practices are essentially a research process to find out the optimal solutions. As one type of the practice research, "prototype study" discussed in this issue offers a paradigm for the innovation of knowledge and methodology. Oriented to future challenges and uncertainties, it would help extend the horizon of Landscape Architecture, providing designers and scholars with prospective design insights and flexible working methods. LAF

\section{REFERENCES}

[1] Ministry of Education of the People's Republic of China. (2020, February 20). Notice from the Ministry of Education and the Ministry of Science and Technology on Issuing "Several Opinions on Regulating the Use of Related Indicators of SCI Papers in Colleges and Universities to Establish Rational Evaluation Orientation". Retrieved from http.//www.moe. gov.cn/srcsite/A16/moe 784/202002/ t20200223_423334.html

[2] Lu, J. (2008). Interpretation of Marxism Literature. Beijing: China Social Sciences Press.

[3] Zeng, S. (2018). The Great Learning (Q. Liu, Tran.). Nanjing: Phoenix Science Press. 